\title{
Children Psychosocial Development: An Effort to Manage the Knowledge on Child Refugees in Indonesia
}

\author{
Erika Chrisiani ${ }^{1}$, Johanna Debora Imelda ${ }^{2}$ \\ Fakultas FISIP Universitas Indonesia, Gedung Nusantara II Kampus FISIP UI, Indonesia ${ }^{\text {I,2 }}$ \\ \{erikachrisiani@gmail.com ${ }^{1}$, johanna.deborah09@ui.ac.id $\left.{ }^{2}\right\}$
}

\begin{abstract}
Stateless refugees in Indonesia, especially children, encounter long-time obscurity and scarcity of resources before being placed in a destination country. As an effort to manage the knowledge of child refugees, this study discusses how parents contribute to their psychosocial development. This study uses qualitative research with indepth interviews and document studies. Interviews were conducted with refugee children who were Cisarua Refugee Learning Center (CRLC) students, aged 14-16, their parents, and teachers in West Java. This study suggests that, first, refugee children were advanced in psychosocial development for their ages, especially in the development of vision, ideals, and views of the future. Second, parents' socialization and the environment greatly affected refugee children's psychosocial development. Third, the environment integrated into the community-based organization (CRLC) contributed effectively to their development. Therefore, there must be family empowerment and institutionalization of community-based organizations in refugee camps for stateless children to develop properly.
\end{abstract}

Keywords: Child Welfare, Community, Empowerment, Family, Identity, Psychosocial Development, Refugee Children Learning Centre.

\section{Introduction}

Although Indonesia is a transit country for refugees, unfortunately, the Indonesian government has not ratified the Convention Relating to the Status of Refugees (1951), so it is not obliged to meet the needs of refugees. For one thing, refugees residing in Indonesia face long waits before being placed in destination countries. Unfortunately, child refugees are victims in this matter. Based on data from UNHCR Indonesia, as of August 2015, there were 3672 child refugees and registered asylum seekers, including 1133 unaccompanied children or children separated from their families [1]. These refugee children are stateless, and nobody is responsible for them. Most likely, then, these children cannot function socially, lack vision or aspirations, and cannot contribute to their social environment.

\section{Literature review}

\subsection{Child Refugee}

The 1951 Convention on Refugee Status defines a refugee as a person who, "owing to well-founded fear of being persecuted for reasons of race, religion, nationality, membership of a particular social group, or political opinion, is outside the country of his nationality, and is unable to or, owing to such fear, is unwilling to avail himself of the protection of that country 
or who, not having a nationality and being outside the country of his former habitual residence as a result of such events, is unable or, owing to such fear, is unwilling to return to it" [2].

Many refugee children are traumatized by their past experiences, and they feel vulnerable due to their incomplete psychosocial development, dependence, and inability to understand events in life [3] Refugee children and adolescents with posttraumatic stress disorder (PTSD) exhibit such symptoms as behavior changes, pessimistic expectations, and imitation of violent behavior [3]. Earnest found that child refugees are concerned about their future, worrying about their education, job search opportunities, and their competence in English [4]. Takara found that many refugee children experience symptoms of anxiety, depression, trauma / PTSD, and other problems related to their emotion and behavior [5] Previously, rarely any research has discussed the psychosocial development of stateless refugee children who are uncertain about the future because of long periods of waiting. Thus, this research reveals the state of refugee children's development and contributors to their psychosocial development. Peggy Nickels' research found that for refugee children, a sense of togetherness and belonging in a community is an important factor for their well-being, and their trauma requires a collective response from the community [6]. Schools are the starting point of the community-building process, viewed as a setting for improving competence, fostering respect for diversity, and buffering children from negative consequences of difficult experiences, such as war and refugees [6].

\subsection{UNICEF Child Protection and Welfare Framework}

\subsubsection{The dimension of Children's Developmental Needs}

This dimension has several indicators, i.e., health, education, emotional development and behavior, identity, family and social relationships, social presentations, and self-care skills [7]. The identity indicator was chosen to examine refugee children's psychosocial development in two affected conditions, i.e., as refugees and as adolescents. In their condition as refugees, children are forced to leave their home country and withdraw their citizenship status. Then, they may lose their sense of identity as citizens and quite literally become stateless. The second thing that affects their identity is the condition of their developmental stage as adolescents in typical identity confusion. Both of these conditions affect refugee children's understanding of themselves, their abilities, self-image and self-confidence, positive feelings about individuality, and their sense of belonging and acceptance.

\subsubsection{The dimension of Parenting Capacity}

The dimension of parenting capacity also has several indicators, among others: basic care, safety assurance, emotional warmth, stimulation, stability, guidance, and restrictions [7]. The emotional warmth indicator is used here to review research findings. Certainly, meeting a child's emotional needs provides a sense of respect and a positive racial and cultural identity.

In the dimension of parenting capacity, an influential indicator is an emotional warmth, in which parents provide children with appreciation, praise, and encouragement [7]. It affects the children in how they see and value themselves. The provision of emotional warmth in a family environment is needed to help these refugee children have a sense of identity and safety so that despite a long waiting period in Indonesia, they have a family to support them. 
Emotional warmth also has an important effect in establishing children's identity. Children remember words of motivation and affection spoken by parents, and that affects how children think and act. Thus, child refugees' level of maturity and fulfillment of their Developmental Needs is influenced by Parenting Capacity, particularly by the provision of emotional warmth.

\subsubsection{The dimension of Family and Environmental Factors}

Indicators of the Family and Environmental Dimension include family history and functioning, extended family, housing, employment, income, family social integration, and community resources [7].

Within the dimension of Family and Environmental factors, refugee children's maturity level is influenced by media, teachers, and the existence of an environment instituted by a community-based organization (CBO). In this study, the indicator of community resources is used, specifically the Cisarua Refugee Learning Center (CRLC), which was established and managed by the refugee community itself.

\subsection{Psychosocial Development Theory}

In addition to the dimensions described above, Erik Erikson's Psychosocial Development Theory [8] is used to analyze the psychosocial development of children in refugee camps.

The concept used in this research was adapted to the ages of the refugee children who became informants, namely, the stage of identity versus identity confusion. The stage of identity versus identity confusion occurs sometime from the age of 10 to 20 years. This stage shows that adolescents want to find out who they are, that is, their identity, and where they will live. When teenagers know positively about existing roles, they will develop a positive identity and when they do not, they will experience confusion about their identity[8]. In Santrock [8] adolescents in search of an identity "try on" or "try out" a variety of identities, roles, and personalities. They may want to become engineers one month and then aspire to another profession the following month. Those who successfully deal with identity-related conflicts develop acceptance of themselves, but teenagers who fail to deal with this identity crisis experience identity confusion. Such confusion's impact is usually marked by teenagers' withdrawal from their families and peers.

At this stage, adolescents are confronted by questions of who they are and where they will live. Questions about identity continue to emerge throughout life, yet this stage is crucial for teens because they face many important choices and are increasingly aware that they will be responsible for themselves and their own lives. Therefore, they are looking for the kind of life they really want to live.

\section{Method}

This research is descriptive and uses a qualitative approach. Data were collected by implementing functional participant observation and in-depth interviews. Research informants were child refugees ( 5 people), cared for by the Cisarua Refugee Learning Center (CRLC), West Java, ranging in age from 14 to 16 years. In addition to the child refugees, CRLC parents (5 people) and teachers ( 5 people) were also interviewed for triangulation and completeness of data.

Data were collected through the non-probability sampling method using purposive sampling. Purposive sampling is appropriate when a researcher wants to involve informants 
who meet certain criteria [9]. To be able to experience the nature of refugee children's problems, researchers also stayed with the refugee community for two months. Qualitative data analysis was done manually by creating axial coding of interview transcripts written verbatim. Initials were used instead of informants' real names to protect their privacy.

Key informants were refugee children, 14 to 16, from Asia and the Middle East. They had been studying at the CRLC for a minimum of 6 months, and they have been in Indonesia since 2014 or, at least, for the last six months. Informants live not only with their immediate families but also with their extended families. They learned about the CRLC from other refugees. Before enrolling in the CRLC, informants felt immense boredom due to lack of activity. They tended to stay at home and were reluctant to leave their houses because they could speak neither English nor Bahasa Indonesia.

Before entering Indonesia, informants and their families felt great fear because of their background as Hazara. A large percentage of refugees in Indonesia are ethnically Hazara, Shi'ite Muslims originating from Sunni-dominant Afghanistan and Pakistan. Historically, Hazaras have been subject to systematic persecution in Afghanistan [10]. For fear of being targeted and persecuted by the Taliban, they fled their home country.

\section{Result and discussion}

This research revealed three interesting findings. First, child refugees were more mature than their peers, especially in the development of their vision, ideas, and future outlook. They already know their ambitions and aspirations and what they want to do in the future. They also know what they must do to reach their goals so that they have equipped themselves with training skills they think can be useful for reaching their goals. This maturity shows that they do not experience identity confusion despite the difficult and uncertain situation in the refugee camp.

Second, the socialization of parents and the supportive environment greatly contribute to the children's maturity in refugee camps. Indeed, parents play an important role in their children's developmental needs. This study found that parents help children develop their ideas and encourage them to develop their abilities. Parents' motivational words cause children to have a passion for life. Despite refugees having limitations in fulfilling their children's needs, parental socialization provides moral support and motivation for children so that they do not easily give up and continue to fight for what they want.

In addition to parents, as an environmental influence, media play a role in children's formation of ideas and future views, whether the form is a book, movie, documentary or the Internet all informants interviewed said that their current ideals or dreams began when they watched a movie or documentary and read a book.

Third, the study also revealed that the environment contributes more effectively if it is integrated into a community-based organization (CBO), in this case, the CRLC. The CRLC provides hope for refugee children in Cisarua by giving them an opportunity to continue their education, gain knowledge, socialize with peers, and be productive in all the activities taking place at the CRLC.

This study also found that teachers play an active role in helping children develop their skills and also provide them moral support and encouragement. Teachers serve as models for the refugee children, inspiring them. One thing the children admire about the CRLC teachers is their hard work and dedication. These teachers have great influence through their provision of positive role models and motivation for refugee children and by encouraging them to keep trying and to behave and think positively. Of course, they also play an active role in 
developing children's skills and abilities. Furthermore, they inspire child refugees through their great dedication to providing the best for them, especially since they are not paid. Moreover, the teachers instill values and rules, training the children in values of discipline, respect, and togetherness.

\section{Conclusion}

This study showed that refugee children's high level of maturity is strongly influenced by their parents' socialization and the existence of an environment instituted by the Cisarua Refugee Learning Center (CRLC). Parenting Capacity and Family and Environmental Factors greatly contribute to the psychosocial developmental maturity of stateless children, who can function well socially and sustain ideals for the future despite being in a closed, uncertain environment due to long waiting times for resettlement. Therefore, for stateless children to develop properly, there must be family empowerment and institutionalization of communitybased organizations in refugee camps.

\section{References}

[1] UNHCR, "Indonesia factsheet," 2016. [Online]. Available: http://www.unhcr.org/protection/operations/50001bda9/indonesia-fact-sheet.html.

[2] UNHCR, United Nations High Commissioner for Refugees. Geneva, Switzerland: UNHCR, 2011.

[3] T. Thomas and W. Lau, Psychological well being of child and adolescent refugee and asylum seekers: Overview of major research findings of the past ten years. Sydney: Human Rights and Equal Opportunity Commission, 2000.

[4] J. Earnest, "Adolescent and Young Refugee Perspectives on Psychosocial Well-being," Int. J. Humanit. Annu. Rev., vol. 3, no. 5, pp. 79-86, 2006.

[5] S. Takara, "Exploring the psychosocial needs of refugee/asylum-seeking children and youth in Western Canada," Adler School of Professional Psychology, USA, 2014.

[6] P. Nickels, "Planning and developing school-based community supports for refugee children," Wilfrid Laurier University, 1999.

[7] J. Hutton, C. Clarke, and J. Smith, Framework for the Assessment of Children in Need and their Families. London: Department of Health, Home Office and Department for Education and Employment, 2000.

[8] J. W. Santrock, A topical approach to life-span development. New York: McGrawHill Education, 2014.

[9] A. Blackstone, Principles of sociological inquiry. Washington: Saylor Foundation, 2014.

[10] L. R. Briskman and L. I. Fiske, "Asylum seekers and refugees in Indonesia: Problems and potentials," Cosmop. Civ. Soc. An Interdiscip. J., vol. 8, no. 2, pp. 22-42, Jul. 2016. 